\title{
Analysis of Classroom Teaching Candidates' Speaking Self-efficacy in Terms of Different Variables
}

Oğuzhan Kuru*

Faculty of Education, Kahramanmaraş Sütçü İmam Üniversity, Avşar Yerleşkesi, Turkey

Corresponding author: Oğuzhan Kuru, E-mail: okuru82@hotmail.com

\section{ARTICLE INFO}

Article history

Received: June 06, 2018

Accepted: July 19, 2018

Published: July 07, 2018

Volume: 6 Issue: 3

Conflicts of interest: None

Funding: None

\begin{abstract}
Human beings are social creatures by nature and one of their most important characteristics is the multifaceted communication they establish with their environment. There are numerous ways of establishing communication. However, the most preferred manner has always been speech. For the speaking skill to be used effectively, the individual should have self-confidence. Educational institutions are the places where the foundations of self-confidence are laid. In educational institutions where self-confidence is taught, it is fundamental that the educators have self-confidence themselves. The purpose of this study is to determine whether the selfefficacy levels of classroom teacher candidates, who will be teaching in primary schools where the basic characteristics of the speaking skill are taught, display any differences in terms of different variables. The study group of the study consists of students receiving education at the Department of Primary School Teaching, Faculty of Education in a state university in the 2016-2017 academic year. The study group consists of 225 students who were selected through the typical case sampling method, which is one of the purposeful sampling types. With the purpose of collecting data, the 'Speaking Self-Efficacy Scale (SSES)' developed by Aydın (2013) consisting of four sub-dimensions with a Cronbach Alpha value of 0.95 was used. SPSS software program (Version 22) was used in the analysis of numeric data. The data was analyzed with the Independent Sample t-test, One Way ANOVA and Kruskal-Wallis tests. According to the results of the study, a significant difference has been determined in the speaking process and listener factor sub-dimensions of the students in favor of the male students. Regarding the grade levels, it was concluded that the upper grade levels regarded themselves as more self-sufficient in the skill of speaking in all of the sub-dimensions.
\end{abstract}

Key words: Classroom Teaching, Skill of Speaking, Speaking Self-efficacy

\section{INTRODUCTION}

One of the basic aspects which distinguishes humans from other beings is the skill of establishing communication using language. Language is one of the important tools which allows humans to establish communication and maintain communication in an appropriate manner (Akın, 2016). Therefore, what keeps humans together is language. Efficient use of language requires establishing an efficient communication as well. Therefore, healthy communication is, without doubt, directly proportional with the individual's skill of using language (Aydın, 2013; Er \& Demir, 2013). Linguistic skills are generally grouped as listening, reading, writing and speaking. Listening and reading are receptive skills, whereas writing and speaking are productive skills (Hamzadayı \& Büyükikiz, 2015). Whether these skills are used efficiently or not is one of the most important factors in a person's social success. Within the scope of these skills, humans attempted to meet the need to attain success in various ways and first began to use their voice and then attributing meaning to these sounds (Dülger, 2011). As a consequence of this, 'speech,' which is the easiest and most efficient manner of communication, came into existence. In its simplest term, speech is a process which begins in the mind and is completed with the expression of thoughts in verbal form (Er \& Demir, 2013).

A significant part of the individual's daily life is made up of speech (Göçer, 2015; Sağlam \& Doğan, 2013). As the skill of speech gives direction to a person's private life, it allows the individual to socialize and have a place in society, besides greatly influencing individuals' work, educational and private life as well (Boylu \& Çangal, 2015). Speech, which has such an important place in individualistic and social life, is also one of the factors which determines success or failure in a person's educational and work life (İşcan \& Karagöz, 2016). Speech is a skill every healthy person has, however, it cannot be stated that each person speaks in an appropriate and efficient manner (Özdemir, 2017). The realization of the skill of speech is firstly closely related to an individual's 
being healthy in physical and physiological terms (Eyüp, 2013). Following this competency, the courses individuals take throughout their educational life from preschool until higher education and the skills they acquire in their families have great importance in having the skill of communication (Aydın \& Başoğlu, 2014). This skill can be overlooked assuming that the student who can speak at a certain level knows how to speak when he/she starts school or it can be pushed into the background. (Sağlam \& Doğan, 2013). However, according to Bernstein (1971), since they are only able to speak a restricted code, working-class children are less effective and successful in communication when compared with middle class children. As a consequence of this working class students have difficulty in understanding the teacher and language in the course books, which results in their long term academic failure if they are not helped at school.

The skill of speech, which the child acquires from his/ her family and environment, continuously needs to be monitored and developed in educational life, starting from primary school including higher education (Aydın \& Başoğlu, 2014). This duty inevitably belongs to teachers. Before anything else, teachers need to speak in an accurate, nice and effective manner to be able to be successful in their occupations and to become good role models for their students, because teachers' problems in speech affect society in general and in particular the students and this results in lack of effective speaking skills among students. Therefore, students correct their mistakes in their own speech by listening to and watching their teachers whom they see as role models unconsciously. In short, it is mandatory that teachers speak the language they use in an understandable manner (Katranc1, 2014; Akkaya, 2012; Uçgun, 2007; İşisağ \& Demirel, 2010).

In reality, anxiety should be at a low or medium level for speech performance to take place in the desired manner (Özdemir, 2018). However, if the anxiety is high, its negative effects increase as well (Demir, 2010). In working class, women and children are supposed to keep silent. They are generally communicated through body language. When children ask some questions about what is going on in their environment, they are not usually answered. What is worse, they are scolded if they wonder about something unsuitable for their age. Therefore, working class children feel unwilling to speak and ask questions in classroom as well (Savaş, 2017). In order to be able to overcome a high level of anxiety concerning speech, it is mandatory that the individuals have confidence in themselves (Uçak \& Gökçü, 2015). The belief that they can be successful in speech, forms the foundation of this confidence. An individual's self-evaluation about having a certain amount of efficiency is defined with the concept of self- efficacy (Katranc1, 2014). Self- efficacy is a concept which expresses individuals' carrying out the duties and behaviors which are expected of them, organizing the required activities to present a specific performance and believing in themselves about being successful about a particular duty or situation by overcoming the difficulties they face. At this point, teachers' self- efficacy in speaking gains importance (Kurudayığlu \& Güngör, 2017; Katrancığlu \& Melanlığlu, 2013). Therefore, the acquisition of this skill prior to starting this profession appears before us as an inevitable reality.

The skill of speech is a process which is initiated with learning how to use existing organs such as the mouth, tongue, teeth and palate and continues by learning the grammar rules of the language being used. This is not a skill which can be acquired only by controlling and learning such variables as to use speaking organs. The skill of speech is also closely related to self-confidence besides these variables. Self-confidence is a skill which can be acquired under the supervision of professional environments and professional people as much as possible. According to Vygotsky, if young children are supported by adults around them during language development period when they ask questions about life, their language development speeds up together with their critical thinking skills and cognitive skills (Vygotsky, 1978). Children need this support at school as well. Bruner's Constructive learning theory, like Vygotsky, emphasizes the social nature of learning, citing that other people should help a child develop skills through the process of scaffolding. Scaffolding involves helpful, structured interaction between an adult and a child with the aim of helping the child achieve a specific goal (Bruner, 1978). The places in which individuals come together in such professional environments and people are generally schools. In particular, primary schools are more important in this stage. It is expected from classroom teachers, who teach, supervise and practice the skill of speech, to be effective speakers as much as the students. This study, in which the speaking self- efficacy levels of teacher candidates who have not yet begun their occupations, is regarded as important in the sense that students see their deficiencies, competencies and differences.

As can be understood from the above explanations, self-efficacy expresses the self-confidence about the individual's ability to succeed. In particular, it is a fact that teachers should have this skill. It is difficult to be successful for a teacher who doesn't trust himself/herself and doesn't believe himself/herself in the education system. The speaking skill, which is the basic requirement of the teaching profession, is an important qualification that every teacher should possess. Using this skill effectively is connected with the self-confidence in the community. In their undergraduate education process, teacher candidates are provided with various application opportunities at different grade levels and in different course contents to acquire this skill and learn to trust themselves. During these applications, the teacher candidates gain confidence and effective speaking skills in the community. It is also expected that they will be able to develop this professional skill and use this skill in avoiding the positive or negative effects of gender differences. Because of these reasons, it is an important issue to develop both male and female teacher candidates' speech self-sufficiency skill in different grade levels and different course contents.

The purpose of this study is to determine whether classroom teaching candidates' self- efficacy levels of skill of speaking, which constitutes the foundation of communication and is the basic requirement of the teaching occupation, displays differences in terms of different variables. 
For this purpose, the answers to the following questions have been sought:

1. Are there any differences between the speaking self-efficacy of the teacher candidates in terms of gender?

2. Are there any differences between the speaking self-efficacy of the teacher candidates in terms of grade levels?

3. Are there any differences between the speaking self-efficacy of the male teacher candidates?

Are there any differences between the speaking self-efficacy of the female teacher candidates?

\section{METHOD}

In this study which aims at presenting the speaking self- efficacy levels of classroom teaching candidates, the survey model has been used. The survey model is a research design, in which the participants' views or characteristics such as interest areas, skills, talents, attitudes are determined about a subject or event; samples which can represent a large group are selected and it is based on the answers given to the questions asked to people who are sources of data with the purpose of collecting data (Büyüköztürk, Çakmak, Akgün, Karadeniz \& Demirel, 2010).

\section{Study Group}

The study group of the study consists of students receiving education at the Department of Primary School Teaching, Faculty of Education in a state university in the 2016-2017 academic year. The study group consists of 225 students who have been selected through the typical case sampling method, which is one of the purposeful sampling types. Purposeful sampling method allows the selection of situations which are rich in information depending on the purpose of the study and conducting in-depth research. In addition, typical case sampling requires selecting a typical situation among numerous situations in the population about the research problem and working on this particular problem (Büyüköztürk et al., 2010).

\section{Data Collection Tool and Analysis of Data}

With the purpose of collecting data, the 'Speaking Self-Efficacy Scale (SSES)' developed by Aydın (2013) has been used. The scale consists of four sub-dimensions as planning of speech, speech process, linguistic structure and listener factor. As a result of the reliability analysis of the scale, the Cronbach Alpha coefficient for the whole scale has been determined as.95. The Cronbach Alpha coefficients of the sub-dimensions of the scale are:.94 for planning of speech;.87 for speech process;.89 for linguistic structure and.74 for listener factor.

In addition, the Cronbach Alpha coefficient for the whole scale for this study has been determined as.95. The scale's Cronbach Alpha coefficients of the sub-dimensions have been determined as:.90 for planning of speech;.86 for speech process; .85 for linguistic structure and. 80 for listener factor. The SPSS 22 software program has been used in the analysis of data.
Whether there is a significant difference between the self-efficacy of the teacher candidates during speech in terms of their gender has been analyzed with the Independent Sample t-test and whether there is a significant difference in their self-efficacy levels in terms of their grade levels and gender has been analyzed with the One Way between groups ANOVA and Kruskal-Wallis tests.

\section{FINDINGS}

In this section, the findings related to whether there is a difference between speech self-sufficiencies of the classroom teaching candidates in terms of gender and grade levels have been given place to.

The Independent Sample t-test results of the self- efficacy of the teacher candidates in terms of gender have been presented in Table 1.

In terms of gender, the results of the speaking self- efficacy sub-dimensions and total scores of independent sample t-test for classroom teaching candidates have been presented in Table 1.

In order to answer the first research question, an independent- sample t-test was conducted to see if male and female teacher candidates differed on their speaking self- efficacy. An examination of data indicated that there was not a significant difference in planning speech and linguistic structure, sub-dimensions of self- efficacy, between male and female teacher candidates. However, there was a significant difference in speech process, a sub-dimension of self- efficacy, between males $(M=45.10, S D=7.34)$ and females $(M=40.88$, $S D=5.90)(\mathrm{t}=3.63, \mathrm{p}=0.001, \mathrm{df}=223)$.

In addition, there was a significant difference in the listener factor, a sub-dimensions of self- efficacy, between males $(M=18.78, S D=4.27)$ and females $(M=17.08, S D=$ 3.31) $(\mathrm{t}=2.53, \mathrm{p}=0.014, \mathrm{df}=223)$.

The results of the One Way between groups ANOVA test for the speech self-sufficiencies of the teacher candidates according to grade levels have been given in Table 2 .

In Table 2, the results of the one Way ANOVA test for the four sub-dimensions of the classroom teaching candidates' speech self-sufficiencies have been given and it has been determined that there is a significant difference in all of the sub-dimensions.

In order to answer the second research question, a oneway between groups analysis of variance was conducted to find out if there are significant differences between self- efficacy of teacher candidates in terms of grade levels. There was a statistically significant differences at the $p<0.05$ level in speech self- efficacy scores for four grade levels. The results indicated that in planning of speech, a sub-dimension of self- efficacy, there were significant differences between grade levels 1 and 4, 2 and 4, 3 and 4. The mean score of grade level $1(M=62.60, S D=11.15)$ was significantly different from grade level $4(M=71.02, S D=10.07)$. The mean scores of grade level $2(M=64.19, S D=10.20)$ and grade level $4(M=71.02, S D=10.07)$ were also significantly different from each other. Besides, the mean score of grade level $3(M=65.53, S D=10.09)$ was significantly different from grade level $4(M=71.02, S D=10.07)$. 
Table 1. Independent sample t-test results of teacher candidates' speaking self- efficacy in terms of gender

\begin{tabular}{|c|c|c|c|c|c|c|c|}
\hline Speaking self- efficacy & Gender & n & M & SD & df & $\mathbf{t}$ & p \\
\hline \multirow[t]{2}{*}{ Planning of speech } & Male & 47 & 67.44 & 11.86 & 223 & 1.23 & 0.222 \\
\hline & Female & 178 & 65.10 & 10.46 & & & \\
\hline \multirow[t]{2}{*}{ Speech process } & Male & 47 & 45.10 & 7.34 & 223 & 3.63 & 0.001 \\
\hline & Female & 178 & 40.88 & 5.90 & & & \\
\hline \multirow[t]{2}{*}{ Linguistic structure } & Male & 47 & 30.08 & 6.76 & 223 & 0.049 & 0.961 \\
\hline & Female & 178 & 30.03 & 4.80 & & & \\
\hline \multirow[t]{2}{*}{ Listener factor } & Male & 47 & 18.78 & 4.27 & 223 & 2.53 & 0.014 \\
\hline & Female & 178 & 17.08 & 3.31 & & & \\
\hline
\end{tabular}

Table 2. One way between groups ANOVA results of teacher candidates' speaking self- efficacy in terms of grade levels

\begin{tabular}{|c|c|c|c|c|c|c|c|}
\hline Speaking self- efficacy & Groups & n & M & SD & $\mathbf{F}$ & $\mathbf{p}$ & Difference (LSD) \\
\hline \multirow[t]{4}{*}{ Planning of speech } & $1^{\text {st }}$ grade & 61 & 62.60 & 11.15 & 6.452 & 0.000 & \multirow{4}{*}{$1-4,2-4,3-4$} \\
\hline & $2^{\text {nd }}$ grade & 57 & 64.19 & 10.20 & & & \\
\hline & $3^{\text {rd }}$ grade & 58 & 65.53 & 10.09 & & & \\
\hline & $4^{\text {th }}$ grade & 49 & 71.02 & 10.07 & & & \\
\hline \multirow[t]{4}{*}{ Speech process } & $1^{\text {st }}$ grade & 61 & 37.52 & 6.15 & 23.303 & 0.000 & \multirow{4}{*}{$\begin{array}{c}1-2,1-3,1-4 \\
2-3,2-4 \\
3-4\end{array}$} \\
\hline & $2^{\text {nd }}$ grade & 57 & 40.85 & 4.12 & & & \\
\hline & $3^{\text {rd }}$ grade & 58 & 43.44 & 5.92 & & & \\
\hline & $4^{\text {th }}$ grade & 49 & 46.12 & 6.19 & & & \\
\hline \multirow[t]{4}{*}{ Linguistic structure } & $1^{\text {st }}$ grade & 61 & 27.88 & 5.16 & 9.311 & 0.000 & \\
\hline & $2^{\text {nd }}$ grade & 57 & 29.15 & 4.98 & & & \multirow{3}{*}{$\begin{array}{l}1-3,1-4 \\
2-3,2-4\end{array}$} \\
\hline & $3^{\text {rd }}$ grade & 58 & 31.08 & 5.27 & & & \\
\hline & $4^{\text {th }}$ grade & 49 & 32.53 & 4.38 & & & \\
\hline \multirow[t]{4}{*}{ Listener factor } & $1^{\text {st }}$ grade & 61 & 14.14 & 2.94 & 45.699 & 0.000 & \multirow{4}{*}{$\begin{array}{c}1-2,1-3,1-4 \\
2-3,2-4\end{array}$} \\
\hline & $2^{\text {nd }}$ grade & 57 & 17.19 & 2.72 & & & \\
\hline & $3^{\text {rd }}$ grade & 58 & 19.12 & 2.80 & & & \\
\hline & $4^{\text {th }}$ grade & 49 & 19.83 & 2.90 & & & \\
\hline
\end{tabular}

In speech process, a sub-dimension of self- efficacy, there were significant differences between grade levels 1 and 2, 1 and 3,1 and 4, 2 and 3,2 and 4, 3 and 4. The mean score of grade level $1(M=37.52, S D=6.15)$ was significantly different from grade level $2(M=40.85, S D=4.12)$. The mean score of grade level $1(M=37.52, S D=6.15)$ was significantly different from grade level $3(M=43.44, S D=5.92)$. The mean score of grade level $1(M=37.52, S D=6.15)$ was significantly different from grade level $4(M=46.12, S D=6.19)$. The mean score of grade level $2(M=40.85, S D=4.12)$ was significantly different from grade level $3(M=43.44, S D=5.92)$. The mean score of grade level $2(M=40.85, S D=4.12)$ was significantly different from grade level $4(M=46.12, S D=6.19)$. Besides, the mean score of grade level $3(M=43.44, S D=5.92)$ was significantly different from grade level $4(M=46.12, S D=6.19)$.

In linguistic structure a sub-dimension of self-efficacy, there were significant differences between grade levels 1 and 3, 1 and 4, 2 and 3, 2 and 4. The mean score of grade level 1 $(M=27.88, S D=5.16)$ was significantly different from grade level $3(M=31.08, S D=5.27)$. The mean score of grade level $1(M=27.88, S D=5.16)$ was significantly different from grade level $4(M=32.53, S D=4.38)$. Besides, the mean score of grade level $2(M=29.15, S D=4.98)$ was significantly different from grade level $3(M=31.08, S D=5.27)$ and the mean score of grade level $2(M=29.15, S D=4.98)$ was significantly different from grade level $4(M=32.53, S D=4.38)$.

In listener factor, a sub-dimension of self- efficacy, there were significant differences between grade levels 1 and 2, 1 and 3, 1 and 4, 2 and 3, 2 and 4. The mean score of grade level $1(M=14.14, S D=2.94)$ was significantly different from grade level $2(M=17.19, S D=2.72)$. The mean score of grade level $1(M=14.14, S D=2.94)$ was significantly different from grade level $3(M=19.12, S D=2.80)$. The mean score of grade level $1(M=14.14, S D=2.94)$ was significantly different from grade level $4(M=19.83, S D=2.90)$. Besides, the mean score of grade level $2(M=17.19, S D=2.72)$ was significantly different from grade level $3(M=19.12, S D=2.80)$. The mean score of grade level $2(M=17.19, S D=2.72)$ was significantly different from grade level $4(M=19.83, S D=2.90)$.

The Kruskal-Wallis test results for the speaking self- efficacy of the male teacher candidates in terms of grade levels have been presented in Table 3 .

In Table 3, the Kruskal-Wallis and Mann Whitney-U tests results for the speaking self- efficacy of the male teacher 
Table 3. Kruskal-wallis and mann whitney-U tests results of male teacher candidates' speaking self- efficacy in terms of grade levels

\begin{tabular}{lllccccc}
\hline Speaking self- efficacy & Groups & $\mathbf{n}$ & Mean rank & SD & $\mathbf{x 2}$ & $\mathbf{p}$ & Difference (Mann-whitney-U) \\
\hline Planning of speech & $1^{\text {st }}$ grade & 10 & 15.65 & 3 & 26.28 & 0.000 & $1-4,2-4$, \\
& $2^{\text {nd }}$ grade & 12 & 14.38 & & & & $3-4$ \\
& $3^{\text {rd }}$ grade & 12 & 23.79 & & & & $1-3,1-4$, \\
Speech process & $4^{\text {th }}$ grade & 13 & 39.50 & & & & $2-3,2-4$, \\
& $1^{\text {st }}$ grade & 10 & 12.65 & 3 & 31.16 & 0.000 & $3-4$ \\
Linguistic structure & $2^{\text {nd }}$ grade & 12 & 15.75 & & & & $1-3,1-4$, \\
& $3^{\text {rd }}$ grade & 12 & 23.38 & & & & $2-3,2-4$, \\
& $4^{\text {th }}$ grade & 13 & 40.92 & & & & $3-4$ \\
& $1^{\text {st }}$ grade & 10 & 16.35 & 3 & 20.13 & 0.000 & $1-3,1-4$, \\
& $2^{\text {nd }}$ grade & 12 & 14.04 & & & & $2-3,2-4$, \\
Listener factor & $3^{\text {rd }}$ grade & 12 & 27.33 & & & & $3-4$ \\
\hline
\end{tabular}

candidates in terms of grade levels have been presented and it has been found out that there is a significant difference in all of the sub-dimensions.

In order to answer the third research question, Kruskal-Wallis and Mann Whitney-U tests analysis of variance was conducted to find out if there are significant differences between self- efficacy of teacher candidates in terms of grade levels. There was a statistically significant differences at the $\mathrm{p}<0.05$ level in speech self- efficacy scores for four grade levels. The results indicated that in planning of speech, a sub-dimension of self- efficacy, there were significant differences between grade levels 1 and 4, 2 and 4, 3 and 4. The mean score of grade level $1(M=15.65, S D=3)$ was significantly different from grade level $4(M=39.50, S D=3)$. The mean scores of grade level $2(M=14.38, S D=3)$ and grade level $4(M=39.50, S D=3)$ were also significantly different from each other. Besides, the mean score of grade level 3 $(M=23.79, S D=3)$ was significantly different from grade level $4(M=39.50, S D=3)$.

In speech process, a sub-dimension of self- efficacy, there were significant differences between grade levels 1 and 3, 1 and 4, 2 and 3,2 and 4, 3 and 4. The mean score of grade level $1(M=12.65, S D=3)$ was significantly different from grade level $3(M=23.38, S D=3)$. The mean score of grade level $1(M=12.65, S D=3)$ was significantly different from grade level $4(M=40.92, S D=3)$. The mean score of grade level $2(M=15.75, S D=3)$ was significantly different from grade level $3(M=23.38, S D=3)$. The mean score of grade level $2(M=15.75, S D=3)$ was significantly different from grade level $4(M=40.92, S D=3)$. Besides, the mean score of grade level $3(M=23.38, S D=3)$ was significantly different from grade level $4(M=40.92, S D=3)$.

In linguistic structure process, a sub-dimension of self-efficacy, there were significant differences between grade lev- els 1 and 3, 1 and 4, 2 and 3,2 and 4, 3 and 4. The mean score of grade level $1(M=16.35, S D=3)$ was significantly different from grade level $3(M=27.33, S D=3)$. The mean score of grade level $1(M=16.35, S D=3)$ was significantly different from grade level $4(M=36, S D=3)$. The mean score of grade level $2(M=14.04, S D=3)$ was significantly different from grade level $3(M=27.33, S D=3)$. The mean score of grade level $2(M=14.04, S D=3)$ was significantly different from grade level $4(M=40.92, S D=3)$. Besides, the mean score of grade level $3(M=27.33, S D=3)$ was significantly different from grade level $4(M=36, S D=3)$.

In listener factor, a sub-dimension of self- efficacy, there were significant differences between grade levels 1 and 3, 1 and 4, 2 and 3, 2 and 4, 3 and 4. The mean score of grade level $1(M=9.05, S D=3)$ was significantly different from grade level $3(M=31.04, S D=3)$. The mean score of grade level $1(M=9.05, S D=3)$ was significantly different from grade level $4(M=38.65, S D=3)$. The mean score of grade level $2(M=13.54, S D=3)$ was significantly different from grade level $3(M=31.04, S D=3)$. The mean score of grade level $2(M=13.54, S D=3)$ was significantly different from grade level $4(M=38.65, S D=3)$. Besides, the mean score of grade level $3(M=31.04, S D=3)$ was significantly different from grade level $4(M=38.65, S D=3)$.

The results of the One Way between groups ANOVA test for the speech self-sufficiencies of the female teacher candidates regarding grade levels have been given in Table 4

In Table 4, the results of the One Way ANOVA test for the speech self-sufficiencies of the female teacher candidates according to grade levels have been given and a significant difference in the planning of speech sub-dimension has not been found. However, it has been revealed that there is a significant difference in the speech process, linguistic structure and listener factor self- efficacy levels. 
Table 4. One way between groups ANOVA results of female teacher candidates' speaking self- efficacy in terms of grade levels

\begin{tabular}{|c|c|c|c|c|c|c|c|}
\hline Speaking self- efficacy & Groups & $\mathbf{n}$ & $\mathbf{M}$ & SD & $\mathbf{F}$ & p & Difference (LSD) \\
\hline \multirow[t]{4}{*}{ Planning of speech } & $1^{\text {st }}$ grade & 51 & 63.13 & 11.61 & 1.24 & 0.296 & \multirow{8}{*}{$\begin{array}{c}1-2,1-3,1-4 \\
2-3\end{array}$} \\
\hline & $2^{\text {nd }}$ grade & 45 & 65.51 & 10.78 & & & \\
\hline & $3^{\text {rd }}$ grade & 46 & 65.04 & 9.86 & & & \\
\hline & $4^{\text {th }}$ grade & 36 & 67.47 & 8.84 & & & \\
\hline \multirow[t]{4}{*}{ Speech process } & $1^{\text {st }}$ grade & 51 & 37.03 & 6.32 & 14.49 & 0.000 & \\
\hline & $2^{\text {nd }}$ grade & 45 & 40.86 & 4.46 & & & \\
\hline & $3^{\text {rd }}$ grade & 46 & 43.47 & 5.85 & & & \\
\hline & $4^{\text {th }}$ grade & 36 & 43.05 & 3.84 & & & \\
\hline \multirow[t]{4}{*}{ Linguistic structure } & $1^{\text {st }}$ grade & 51 & 28.11 & 5.38 & 4.48 & 0.005 & \multirow{4}{*}{$1-2,1-3,1-4$} \\
\hline & $2^{\text {nd }}$ grade & 45 & 30.17 & 4.15 & & & \\
\hline & $3^{\text {rd }}$ grade & 46 & 30.95 & 4.57 & & & \\
\hline & $4^{\text {th }}$ grade & 36 & 31.38 & 4.27 & & & \\
\hline \multirow[t]{4}{*}{ Listener factor } & $1^{\text {st }}$ grade & 51 & 14.19 & 3.15 & 26.72 & 0.000 & \multirow{4}{*}{$1-2,1-3,1-4$} \\
\hline & $2^{\text {nd }}$ grade & 45 & 17.73 & 2.70 & & & \\
\hline & $3^{\text {rd }}$ grade & 46 & 18.45 & 2.72 & & & \\
\hline & $4^{\text {th }}$ grade & 36 & 18.61 & 2.27 & & & \\
\hline
\end{tabular}

In order to answer the last research question, a oneway between groups analysis of variance was conducted to find out if there are significant differences between speech self-efficacy of female teacher candidates regarding their grade levels. There was statistically significant difference at the $p<05$ level in teacher candidates' speech self- efficacy for four grade levels.

Post hoc comparison using LSD adjustment indicated that regarding speech process, a sub-dimension of self- efficacy, the mean score of grade level $1(M=37.03, S D=6.32)$ was significantly different from grade level $2(M=40.86$, $S D=4.46)$. Also, the mean scores of grade level $1(M=37.03$, $S D=6.32)$ and grade level $3(M=43.47, S D=5.85)$ were significantly different from each other. The mean score of grad level $1(M=37.03, S D=6.32)$ was significantly different from grade level $4(M=43.05, S D=3.84)$. Besides, the mean score of grade level $2(M=40.86, S D=4.46)$ was significantly different from grade level $3(M=43.47, S D=5.85)$.

In linguistic process, a sub-dimension of self- efficacy, there were significant differences between grade levels 1 and 2,1 and 3,1 and 4. The mean score of grade level $1(M=28.11$, $S D=5.38)$ was significantly different from grade level 2 $(M=30.17, S D=4.15)$. Also, the mean scores of grade level $1(M=28.11, S D=5.38)$ and grade level $3(M=30.95, S D=$ 4.57) were significantly different from each other. Besides, the mean score of grad level $1(M=28.11, S D=5.38)$ was significantly different from grade level $4(M=31.38, S D=4.27)$.

In listener factor, a sub-dimension of self- efficacy, there were significant differences between grade levels 1 and 2, 1 and 3, 1 and 4. The mean score of grade level $1(M=$ $14.19, S D=3.15)$ was significantly different from grade level $2(M=17.73, S D=2.70)$. Also, the mean scores of grade level $1(M=14.19, S D=3.15)$ and grade level $3(M=18.45$, $S D=2.72$ ) were significantly different from each other. Be- sides, the mean score of grad level $1(M=14.19, S D=3.15)$ was significantly different from grade level $4(M=18.61$, $S D=2.27$ )

\section{DISCUSSION AND CONCLUSION}

According to the findings of the study, a significant difference has not been found in the speaking self- efficacy of the teacher candidates receiving education at the department of primary education in terms of the planning of speech, linguistic structure and listener sub-dimensions, however, a significant difference has been detected only in the speech process sub-dimension in the favor of the male teacher candidates $(M=45.10$ (Males), $M=40.88$ (Females)). In the case of the grade levels regardless of gender, a significant difference has been found in all of the sub-dimensions of the speaking self- efficacy of the teacher candidates. According to this result, it has been seen that as the students' grade levels increase, so does their speaking self- efficacy.

A significant difference has been found in the speaking self- efficacy of the male teacher candidates in terms of their grade levels. According to this result, it has been seen that the male teacher candidates feel more self-sufficient between the grades 1-4,2-4,3-4 in terms of planning of speech in the favor of the senior students and similarly, between the grades $1-3,1-4,2-3,2-4,3-4$ in terms of speech process, linguistic structure and listener sub-dimensions in the favor of the upper grades. A significant difference has not been observed in the planning of speech of female teacher candidates, whereas a significant difference has been found between grades $1-2,1-3,1-4$ in terms of speech process, linguistic structure and listener sub-dimensions.

Taking all of these findings into consideration, it can be stated that the reason why male teacher candidates are more self-confident in terms of speech process is most likely be- 
cause of the fact that they are able to better control the variables required within the process of speech. Since speech process involves aspects such as the use of gestures and mimics, eye contact with the listeners and being able to control their reactions, the place the individual stands, clothes, staying on the subject by avoiding unnecessary emotions and thoughts and breathing control, the male candidates might be thinking that they can be more successful in these. Female teacher candidates' being more thoughtful and giving great importance to details might be causing them to have less self-confidence compared to the male teacher candidates.

In terms of grade levels, the increase in the self-confidence of the teacher candidates in terms of variables related to planning of speech, speech process, linguistic structure and listener factor as their grade levels go up might be regarded as a success of the graduate education they are receiving. The positive effect of being given the chance to speak through the applied courses for the students of all levels throughout their classroom teaching education is inevitable. With the help of these applied courses, the students in particular learn about planning speech with the lesson plans or speech texts they create, are able to control the listeners since they speak before their classmates, learn the details of their own language through the Turkish classes they take, get to learn about the structure of language and even if they make mistakes, immediately being corrected allows them to use language accurately and control it. Besides all these, in particular the positive self-confidence the students acquire in their last year might be considered the consequence of the prepared and spontaneous speech activities they carry out in their effective communication class through the micro teaching technique.

Similarly, the male teacher candidates having more self-confidence in a systematic manner as their grade level goes up in all of the dimensions of speech is considered to be the result of getting to know the language with all its dimensions through their graduate lessons and learning to use it expertly, besides being able to easily control the variables of speech.

Female teacher candidates being able to successfully use the process of speech and linguistic structure and control the listeners in their own favor and not being affected negatively from the listeners are regarded similarly as the result of the applications they carry out throughout their graduate education. It has been seen that the female teacher candidates do not display a difference only in terms of planning speech. This might be due to the fact that they do not feel the need to plan their speeches and think that they can spontaneously speak and be successful in that manner.

Similar to this study, it can be seen in Akın's study (2016) on speaking self-efficacy of Turkish language teacher candidates that, according to the grade level variable, as the grade levels go up self-efficacy increases and that gender does not create a significant difference in speaking self-efficacy. In Katranci's study (2014) on speaking self-efficacy of physical education, science, computer, classroom and Turkish language teacher candidates, it has been determined that the teacher candidates display significant differences in terms of gender and their departments, but that grade level does not lead to a significant difference on the perception of speaking self-efficacy. Similarly, in Eyüp's study (2013) on how university students use their speaking skills, in which faculties and departments were taken as the basis, it has been determined that there is no significant difference in terms of gender. Taking the results of these similar studies into consideration, it may be concluded that the courses taken in the faculties of education in the area of teaching which carry more verbal weight and the in-class applications have a positive contribution on grade levels, but that when teaching areas which carry more numerical weight are in question as seen in Katranc1's study, then this difference disappears. In addition, when the speaking skill is taken into consideration as a whole, it can be stated as a similar result for this study that gender does not create a significant difference.

As a result, even though the skill of speech is necessary for all people and all occupations, it is an indispensable requirement for the profession of teaching. Teachers transmit their knowledge and culture of the society to the new generations through language. In other words, teaching is an occupation carried out through speaking. Therefore, teachers need to use language at a professional level, plan the process and give importance to the listeners. This becomes more important when we consider the fact that students in a particular classroom come from very different social and cultural backgrounds especially in developing and underdeveloped countries and therefore have different linguistics skills and especially when we think that some of them have weaker language skills than the others as mentioned by Bernstein (1971). Therefore, better speaking skills for teachers are also important when we consider the difference between language at home and language at school. We also need to remember that the process of language development, which seems to have been completed in the pre-school period, continues at school, too and children gain new knowledge and skills about phonological, semantic, syntactic and pragmatic rules and practices of language at school. Because the child has to learn both the written and verbal metrical forms of the mother tongue used as educational language. Therefore, the process of acquiring and developing language skills at home continues at school at an increasing speed and intensity (Savaş, 2017). For these reasons, it is expected throughout graduate education to make it possible for all classroom teaching candidates to acquire this skill and begin their profession with it.

Based on the above conclusions, the following suggestions are made to the teacher training institutes, teacher candidates and new research in the field. If possible, students can be given an opportunity to speak in each of their classes and their progress and mistakes about the speech process can be corrected in real time. The classes planned by the lecturers can be designed to encourage students of all grade levels to speak. Students can be given the chance to present prepared and spontaneous speeches and experience different types of speech. Students can be given speech related tasks outside of their classes and asked them to speak about different subjects before different listener groups. 


\section{REFERENCES}

Akın, E. (2016). Türkçe Öğretmen Adaylarının Konuşma Öz Yeterliliklerinin Çeşitli Değişkenler Açısından İncelenmesi (Siirt Üniversitesi Örneği). Route Educational and Social Science Journal, 3(1), 75-90.

Akkaya, A. (2012). Öğretmen Adaylarının Konuşma Sorunlarına İlişkin Görüşleri. Mustafa Kemal Üniversitesi Sosyal Bilimler Enstitüsü Dergisi, 9(20), 405-420.

Aydın, E. \& Başoğlu, N. (2014). Çağrı Merkezi Hizmetleri Programı Öğrencilerinin Konuşma Becerileri Özyeterlik Algıları: Çaycuma Meslek Yüksekokulu Örneği. Elektronik Mesleki Gelişim ve Araştırmalar Dergisi, 2(3), 33-43.

Aydın, İ.S. (2013). Öğretmen Adaylarının Konuşma Öz Yeterliklerine İlişkin Ölçek Geliştirme Çalışması. Akdeniz Eğitim Araştırmaları Dergisi, 14, 33-46.

Bernstein, B. (1971). A Socio-Linguistic Approach to Social Learning. In B. Bernstein (Ed.). Class, Codes and Control, Volume I. (pp. 118-143) London: Routledge \& Kegan Paul.

Boylu, E. \& Çangal, Ö. (2015). Yabancı Dil Olarak Türkçe Öğrenen Bosna-Hersekli Öğrencilerin Konuşma Kaygılarının Çeşitli Değişkenler Açısından İncelenmesi. Uluslararası Türkçe Edebiyat Kültür Eğitim Dergisi, 4(1), 349-368.

Bruner, J. S. (1978). The role of dialogue in language acquisition. In A. Sinclair, R., J. Jarvelle, and W. J.M. Levelt (eds.) The Child's Concept of Language. New York: Springer-Verlag.

Büyüköztürk, Ş., Çakmak, K.E., Akgün, E.Ö., Karadeniz, Ş., \& Demirel, F. (2010). Bilimsel Araştırma Yöntemleri. Ankara: Pegema Yayıncılık

Demir, T. (2010). Konuşma Eğitiminde Benmerkezci Konuşmaya Yönelik Bir Deneme. Kastamonu Eğitim Dergisi, 18(2), 415-430.

Dülger, M. (2011).Konuşma Becerisinin İlköğretim Öğrencilerine Öğretimi Üzerine Bir İnceleme. (Master thesis). Retrieved from http://acikerisim.deu.edu.tr/xmlui/handle/12345/7049.pdf

Er, O. \& Demir, Ö. (2013). Konuşma Becerisinin Türkçe Öğretmenleri Tarafından Kullanılabilirliğine İlişkin Türkçe Öğretmeni Adaylarının Görüşlerinin İncelenmesi. Turkish Studies International Periodical for the Languages, Literature and History of Turkish or Turkic, 8(1), 1417-1436.

Eyüp, B. (2013). Üniversite Öğrencilerinin Konuşma Becerilerini Kullanmaya Yönelik Tutumları. Milli Eğitim Dergisi, 197, 95-113.
Göçer, A. (2015). Türkçenin Yabancı Dil Olarak Öğretiminde Konuşma Becerisinin Gelişim Durumunun Belirlenmesi. Erzincan Üniversitesi Sosyal Bilimler Enstitüsü Dergisi. Özel Sayl II, 47-56.

Hamzadayı, E. \& Büyükikiz, K.K. (2015). Türkçe Öğrenen Yabancı Öğrencilerin Konuşma Becerisi Öz Yeterlik Algıları İle Kişilik Tipleri Arasındaki İlişki. Türkiye Sosyal Araştırmalar Dergisi, 19(1), 297-312.

İşcan, A. \& Karagöz, B. (2016). TürkçeÖğretmeni Adaylarının Konuşma Kaygılarının İncelenmesi (Gaziosmanpaşa Üniversitesi Örneği). Ahi Evran Üniversitesi Kırşehir Eğitim Fakültesi Dergisi, 17(3), 193-206.

İşisağ, K.U. \& Demirel, Ö. (2010). Diller İçin Avrupa Ortak Başvuru Metni’nin Konuşma Becerisinin Gelişiminde Kullanılması. Eğitim ve Bilim, 35(156), 190-204.

Katrancı, M. (2014). Öğretmen Adaylarının Konuşma Becerisine Yönelik Öz Yeterlik Algıları. Bartın Üniversitesi Ĕgitim Fakültesi Dergisi, 3(2), 174-195.

Katrancıoğlu, M. \& Melanlığlu, D. (2013). Öğretmen Adaylarına Yönelik Konuşma Öz Yeterlik Ölçeği: Geçerlik Ve Güvenilirlik Çalışması. The Journal of Academic Social Science Studies, 6(6), 651-665.

Kurudayığlu, M. \& Güngör, H. (2017). Yabancı Dil Olarak Türkçe Öğrenenlerin Konuşma Öz Yeterliklerinin Çeşitli Değişkenler Açısından İncelenmesi. Uluslararası Türkçe Edebiyat Kültür Eğitim Dergisi, 6(2), 1105-1121.

Özdemir, S. (2018). Türkçe Öğretmeni Adaylarının Konuşma Kaygısını Gidermede Hazırlıklı Konuşmaların Rolü. Abant İzzet Baysal Üniversitesi Eğitim Fakültesi Dergisi, 18(1), 361-374.

Sağlam, Ö. \& Doğan, Y. (2013). 7. Sinıf Öğrencilerinin Hazırlıksız Konuşma Becerileri. Mustafa Kemal Üniversitesi Sosyal Bilimler Enstitüsü Dergisi, 10(24), 43-56.

Savaş, B. (2017). Okuma Eğitimi ve Çocuklarda Dil Gelişimi, Papatyabilim Yayınevi: İstanbul.

Uçak, S. \& Gökçü, E. (2015). Yabancı Dil Olarak Türkçe Öğrenen Öğrencilerin Konuşma Becerisini Geliştirme Stratejileri (Erbil Örneği). Littera Turca journal of Turkish Language and Literature, 1(2), 221-228.

Uçgun, D. (2007). Konuşma Eğitimini Etkileyen Faktörler. Erciyes Üniversitesi Sosyal Bilimler Enstitüsü Dergisi. 22(1), 59-67.

Vygotsky, L. (1978). Mind in society: The development of higher psychological processes. Cambridge, MA: Harvard University Press. 